УДК 669.054:669.054

(C) 2013

Дмитриков В. П., доктор технічних наук,

Падалка В. В., кандидат технічних наук

Полтавська державна аграрна академія

Проценко О. В., кандидат хімічних наук, Коломєєц В. І., викладач

Дніпродзержинський державний технічний університет

\title{
ТЕХНОЛОГІЯ ПЕРЕРОБКИ ВІДПРАЦЬОВАНИХ СВИНЦЕВО-КАДМІЕВИХ ГАЛЬВАНІЧНИХ ЕЛЕМЕНТІВ. ПОВІДОМЛЕННЯ 2. ТЕХНОЛОГІЧНА СХЕМА ПЕРЕРОБКИ
}

\section{Рецензент - доктор педагогічних наук, професор М. В. Гриньова}

\begin{tabular}{|} 
Наведено результати досліджень із реагентної \\
переробки відпрацьованих свинцево-кадмієвих га- \\
льванічних елементів і акумуляторів, які слугують \\
вторинною сировиною для електротехнічної про- \\
мисловості. Розглянуто особливості технологіч- \\
ного проектування, екологічні й економічні аспек- \\
ти переробки. Проаналізовані стадії переробки \\
відпрацьованих свинцево-кадмієвих гальванічних \\
елементів і акумуляторів. Запропонована вдоско- \\
налена методологія і розроблена апаратурно- \\
технологічна схема переробки.
\end{tabular}

Ключові слова: аграрні машини, акумулятори, гальванічні елементи, переробка, технологія утилізаиіï.

Постановка проблеми. Найважливішою частиною технологічного проектування всього підприємства, основних і допоміжних виробничих цехів і установок $€$ створення технологічної схеми, що відображає взаємозв'язок і характер окремих технологічних процесів і устаткування.

Як проектний документ технологічна схема $\epsilon$ графічним зображенням сукупності операцій, що складають закінчений технологічний процес, i супроводжується описом і необхідними розрахунками (розрахунково-пояснювальною запискою) [6].

Специфіка хіміко-механічної поведінки відпрацьованих джерел струму визначає склад i структуру технологічної схеми їх переробки.

Технічний рівень і якість технологічної схеми визначаються детальним опрацьовуванням окремих технологічних вузлів заздалегідь наміченої принципової схеми [4]. Технологічним вузлом зазвичай називають апарат (споруду, машину) або їх групу, в яких починається і повністю закінчується один з етапних процесів, необхідних для досягнення заданого ступеня переробки початкового матеріалу, зокрема вторинного матеріалу для спеціалізованих підприємств, цехів або установок переробки відходів.
Аналіз останніх досліджень та публікацій, у яких започатковано розв'язання проблеми. Раніше [3] були конкретизовані головні напрями утилізації відпрацьованих свинцево-кадмісвих гальванічних елементів і акумуляторів (загальна назва СКЕ). 3 метою вибору оптимального варіанту утилізації відпрацьованих СКЕ доцільно використовувати інформаційно-пошукову та інформаційно-аналітичну системи; за необхідності підключають експертну систему і математичне моделювання [2].

Хімічні перетворення і фізико-технічні процеси, що їх супроводжують, вивчали на подрібненому акумуляторному ломі в умовах $[1,5]$. Відпрацювання технології переробки СКЕ виконували за наслідками лабораторних досліджень, враховуючи особливості їх протікання.

Синтез технологічних схем на основі різноманіття варіантів різних технологічних вузлів проводиться, наприклад, методом динамічного програмування - крокового ухвалення рішень за визначенням оптимального варіанту на основі вибраного критерію оптимальності (мінімуму загальних витрат або максимуму економічного результату, що враховує величину запобіжного збитку навколишньому середовищу або значення плати за дозволене скидання). Важливу роль при цьому відіграють певні евристичні правила (рекомендації). При безперервному процесі забезпечується отримання якіснішої продукції й утворюється порівняно менша кількість відходів, знижуються також втрати сировини і матеріалів. Устаткування для безперервних процесів зазвичай відрізняється більшою продуктивністю. Крім того, безперервні процеси відносно легко піддаються механізації й автоматизації. Їх застосування найраціональніше у виробництвах великої потужності. В окремих випадках у періодичну схему включають безперервно працюючі техноло- 
гічні вузли (ректифікації, екстракції, сушки і т. д.).

Мета та завдання досліджень. Мета: створення технології переробки відпрацьованих СКЕ.

Головне завдання - розробка апаратурнотехнологічної схеми переробки та повної утилізації відпрацьованих СКЕ.

Результати досліджень. На основі проведених досліджень розроблено схему хімічних перетворень СКЕ та апаратурно-технологічну схему утилізації відпрацьованих СКЕ (див. рис.).

Відпрацьовані СКЕ з бункера 1 потрапляють на вальцову дробарку 2, а подрібнений матеріал - у бункер 3 і далі на конвейєр 4 й завантажувальний бункер 5 із дозатором. У реактор 6, обладнаний механічною мішалкою 3 електроприводом, потрапляє подрібнений матеріал із бункера 5 i сірчана кислота з ємності 7 через дозатор 8.

Кадмій і оксид свинцю (IV) розчиняються у сірчаній кислоті з відновленням свинцю (IV) у свинець (II). Надлишок водню через каплевідбійник 9 і холодильник 10 потрапляє до газозбірника 11.

Насос Н подає пульпу з реактора 6 на нутчфільтр 12, котрий безперервно розділяє пульпу на осад і фільтрат. Осад сульфату свинцю (II) після фільтру 12 подає шнек 13 у реактор 14. Для перетворення сульфату свинцю (II) у карбонат свинцю (II) у реактор потрапляє насичений розчин карбонату натрію 3 ємності 15 через дозатор 16. Пульпа з реактора 14 потрапляє на нутч-фільтр 17, котрий іiі безперервно розділяє на осад і фільтрат.

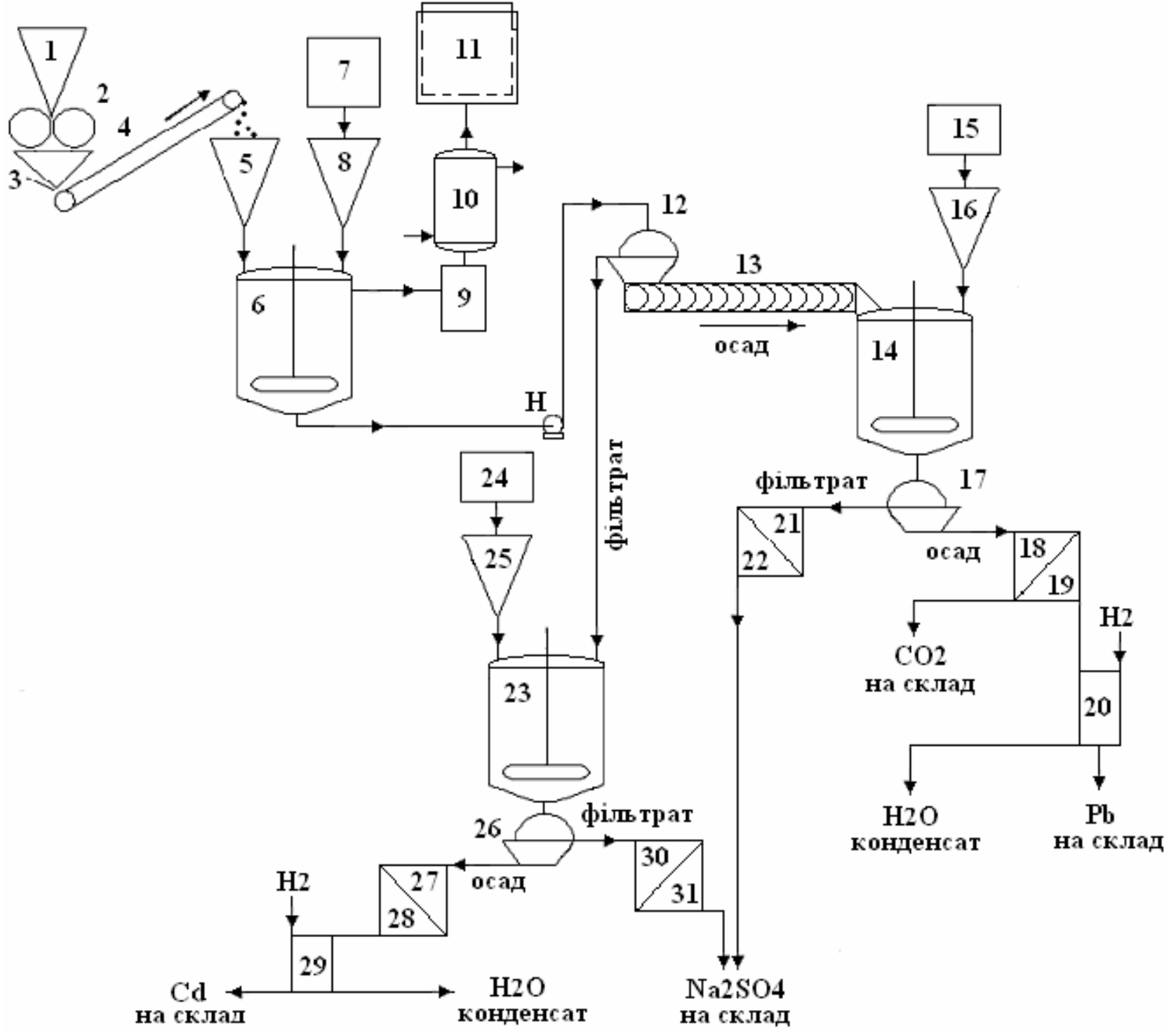

Рис. Апаратурно-технологічна схема переробки відпрацьованих СКЕ 
Осад карбонату свинцю після фільтру 17 піддається сушінню в сушарці 18 і прожарюванню у термокамері 19 з одержанням оксида свинцю (IV) й оксида вуглецю (IV), котрий потрапляє на склад. Оксид свинцю відновлюють у печі 20 до металевого свинцю, що потрапляе на склад, а водяна пара утворює конденсат.

Після фільтру 17 розчин сульфату натрію упарюють у випарці 21 і сушать у сушарці 22, після чого сульфат натрію у вигляді кристалогідрату подають на склад. Фільтрат 12 (розчин сульфату кадмію) після фільтру подають у реактор 23.

Для перетворення сульфату кадмію на гідроксид кадмію у реактор подають концентрований розчин гідроксиду натрію 3 ємності 24 через дозатор 25, а суміш осаду гідроксиду кадмію і розчину сульфату натрію, що утворилася, поступає на фільтр 26. Фільтрат (розчин сульфату натрію) після фільтру 26 подають у випарку 30 і далі на склад у вигляді кристалогідрату.

\section{БІБЛІОГРАФІЯ}

1. Купряков Ю. П. Производство тяжелых цветных металлов из лома и отходов. - Харьков : Основа. $-1992 .-399$ с.

2. Дмитриков В. П. Нечеткости определений экспертной системы мониторинга химических загрязнителей // Вестник НТУ «ХПИ». - 2004. №38. - С. 17-20.

3. Дмитриков В. П. Технологія переробки відпрацьованих свинцево-кадмієвих гальванічних елементів. Повідомлення 1. Принципи переробки хімічні реакції / В. П. Дмитриков, Р. М. Харак, О. В. Проценко, В. І. Коломєєц // Вісник Полтавської держав-
Після фільтру 26 осад гідроксиду кадмію подають у сушарку 27 і термокамеру 28 для отримання сухого гідроксиду кадмію, котрий прокалюють і відновлюють у печі 29 до металевого стану і далі відправляють на склад, а водяна пара утворює конденсат. Об'єднані конденсати водяної пари використовують для приготування розчинів реагентів, котрі потрібні технологічному процесу.

Висновок. Розроблено апаратурно-технологічну схему переробки відпрацьованих СКЕ. Запропонований спосіб дає змогу повернути в сферу виробництва компоненти СКЕ у вигляді товарних продуктів: свинець і кадмій - для електротехнічної промисловості, сполуки свинцю і кадмію - для гальванічної і металургійної промисловості, сульфат натрію - для склоробного виробництва, газоподібний водень і кисень, крихту пластмаси і конденсат знесоленої води - для технічних цілей.

ної аграрної академії. - 2011. - №4. - С. 147-150.

4. Дытнерский Ю.И. Процессы и аппараты химической технологии. В 2-х кн. : Часть 1. Теоретические основы процессов химической технологии. Гидромеханические и тепловые процессы и аппараты. - М. : Химия, 1995. - 400 с.

5. Технология вторичных цветных металлов / И. Ф. Худяков, А. П. Дорошкевич, Э. Кляйн [и др.]. - М. : Металлургия, 1981. - 280 с.

6. Chemical and Process Design Handbook / James G. Speight. - New York etc.: McGraw-Hill. - 2002. $1029 \mathrm{p}$. 